\title{
Orbital Emphysema and Pneumocephalus Caused By Air Gun: Case Report
}

\author{
Hava Tabancasinın Neden Olduğu \\ Orbital Amfizem ve Pnömosefali
}

Kuddusi TEBERIK, ${ }^{a}$

Mehmet Tahir ESKI, ${ }^{a}$ Murat KAYA ${ }^{\mathrm{a}}$

aDepartment of Ophthalmology, Düzce University Faculty of Medicine, Düzce

Geliş Tarihi/Received: 25.06.2015

Kabul Tarihi/Accepted: 30.09.2015

Yazıșma Adresi/Correspondence: Kuddusi TEBERIK

Düzce University Faculty of Medicine, Department of Ophthalmology, Düzce, TÜRKIYE/TURKEY

kuddusiteberik@yahoo.com

\begin{abstract}
Orbital emphysema is a condition occurring as a result of air escape into the orbital cavity due to direct or indirect trauma. Twelve-year-old boy was admitted to our clinic with the complaint of trauma of high-pressure air gun in the left eye occurred during joking. In the ophthalmologic examination of the patient, the visual acuity was found to be $20 / 20$ in both eyes. Intraocular pressure was normal. In the anterior segment examination, swelling around the left eye, proptosis, crepitation, tenderness, and pain were present. In the slit-lamp examination, wide subconjunctival emphysema, subconjunctival hemorrhage at 4-5 o'clock position and about 2-mmlaceration in the conjunctival fornix of the same area were found. Posterior segment examinations of the both eyes were normal. On the physical examination, swelling with crepitation was present on the left side of the face, temporal region and the hairy scalp over the ear. Emphysema and pneumocephalus were detected in the retro-orbital region on the computed tomography examination. Topical antibiotic drops and ointment were given to the patients and prophylactic oral antibiotic and anti-inflammatory treatment were given by department of neurosurgery.
\end{abstract}

Keywords: Subcutaneous emphysema; pneumocephalus; barotrauma

ÖZET Orbital amfizem, direkt veya indirekt travma neticesinde orbitaya hava kaçması sonucu meydana gelen bir durumdur. Oniki yaşında erkek bir çocuk şakalaşma esnasında yüksek basınçlı hava tabancasının sol gözüne sıkılması şikayeti ile kliniğimize başvurdu. Hastanın yapılan oftalmolojik muayenesinde görme düzeyleri her iki gözde 20/20 olarak saptandı. Göz içi basınçları normaldi. Ön segment muayenesinde sol göz çevresinde şişlik, propitozis, krepitasyon, hassasiyet ve ağrı mevcuttu. Kapak ekarte edilerek yapılan biyomikroskopik muayenede yaygın subkonjonktival amfizem, saat 4-5 hizasında subkonjonktival hemoraji ve aynı bölgedeki forniks konjonktivasında yaklaşık $2 \mathrm{~mm}$ 'lik kesi tespit edildi. Arka segment muayenesinde her iki göz de doğal olarak değerlendirildi. Hastanın fizik muayenesinde yüzünün sol tarafında, şakağında ve kulak üstündeki saçlı deride krepitasyon alınan şişlik mevcuttu. Bilgisayarlı tomografi tetkikinde retroorbital bölgede amfizem ve pnömosefali tespit edildi. Hastaya tarafımızca topikal antibiyotik damla ve pomad ile beyin cerrahisi tarafından profilaktik oral antibiyotik ve antiinflamatuar tedavi verildi.

Anahtar Kelimeler: Subkutan amfizem; pnömosefali; basınç travması

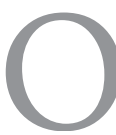

rbital emphysema is a rare condition occurring as a result of air escape into the orbital cavity. ${ }^{1}$ It usually occurs from a broken orbital bone as a result of direct or indirect trauma. ${ }^{2}$

In rare cases, it can be seen as a result of orbital barotrauma associated with coughing, sneezing and vomiting. ${ }^{3}$ 
Fracture in any of the sinuses in the orbital walls causes air intake into the orbita and the most common fracture is seen in the maxillary, ethmoid and frontal sinuses, respectively. ${ }^{4}$ In the high-pressure air gun trauma, the air under pressure is pushed through the subconjunctival space around and behind the orbita and under the skin. Therefore, orbital emphysema development following a conjunctival laceration without orbital wall fracture resulting from the use of air under pressure is a rare condition. ${ }^{5}$ In this article, we are presenting a rare case that emphysema was seen in the subconjunctival, orbital, retro-orbital, intracranial regions and under the scalp due to the trauma of a high pressure air gun.

\section{CASE REPORT}

Twelve-year-old boy was admitted with a complaint of swelling around the eye to Duzce University School of Medicine, Ophthalmology Clinic. Written informed consent forms were obtained from the patient's family. The images of the patient to be used for scientific purposes were picked up with the receipt of written consent. In the medical history, he said that his brother shot air gun accidentally to his left eye during joking. In the ophthalmological examination of the patient, direct and indirect light reflexes in both eyes were natural and eye movements were free in all directions. The visual acuity was found to be $20 / 20$ in both eyes according to the Snellen chart. Intraocular pressure was measured as $15 \mathrm{mmHg}$ in the right eye and $17 \mathrm{mmHg}$ in the left eye with applanation tonometry. In the anterior segment examination, swelling around the left eye, proptosis, crepitation, tenderness, and pain were present. In the slit-lamp examination, common conjunctival bubble formation (Subconjunctival emphysema), subconjunctival hemorrhage at 4-5 o'clock position and about 2-mm-laceration in the conjunctival fornix of the same area were found (Figure 1). In the posterior segment examination with $1 \%$ cyclopentolate, both eyes were evaluated as normal. In the patient's physical examination, swelling with crepitation was present on the left side of the face and around of the left eye (Figure 2). Emphysema and pneu-

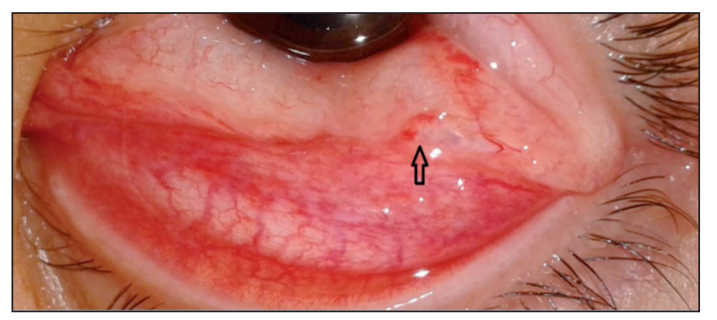

FIGURE 1: Approximately $2 \mathrm{~mm}$ conjunctival laceration, subconjunctival emphysema.

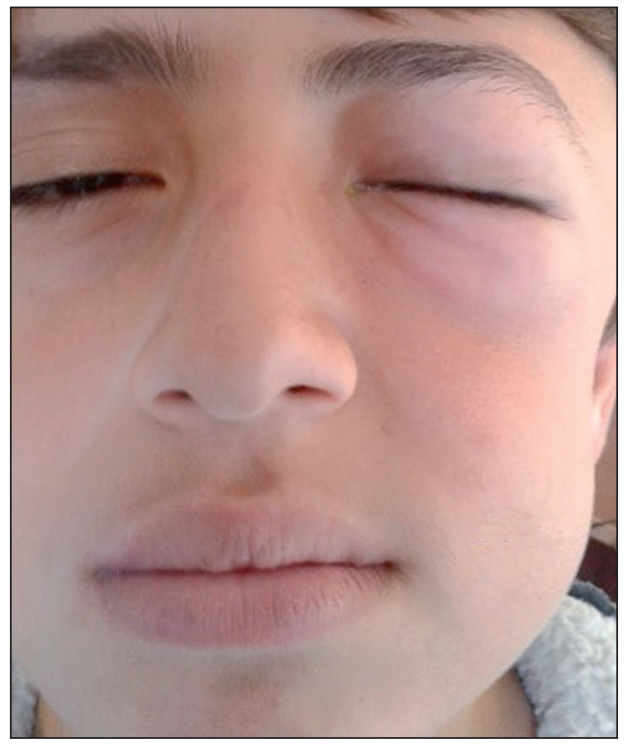

FIGURE 2: Periorbital emphysema, subcutaneous emphysema in the left buccal region and on the left ear.

mocephalus were detected in the retro-orbital region on the computed tomography examination (Figures 3, 4). The patient was hospitalized by department of neurosurgery of our hospital with the diagnosis of pneumocephalus detected in patient and followed for 3 days. Topical antibiotic drops and ointment were given to the patients and prophylactic oral antibiotic and anti-inflammatory treatment were given by brain surgery. Patient was examined every day ophthalmologically. At the end of the $3^{\text {rd }}$ day, orbital emphysema, subconjunctival hemorrhage and conjunctival incision were detected to be partially recovered and the patient was discharged with suggestions of our clinic and department of neurosurgery. It was observed in the first week of control that bleeding and laceration completely disappeared, but orbital emphysema still continued. Patients were included in 


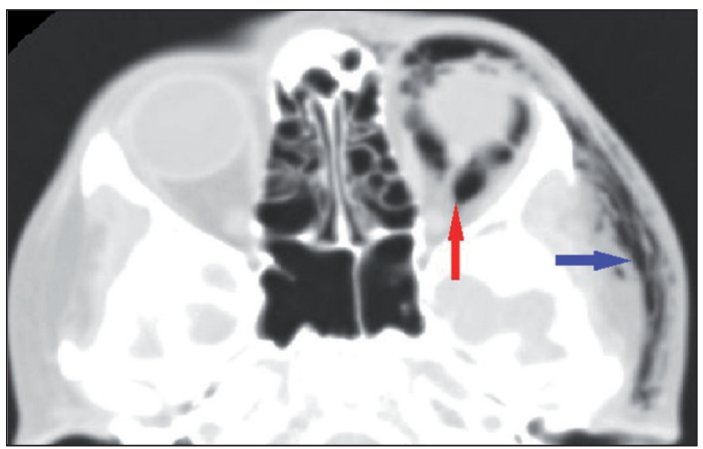

FIGURE 3: Retro-orbital emphysema and subcutaneous emphysema.

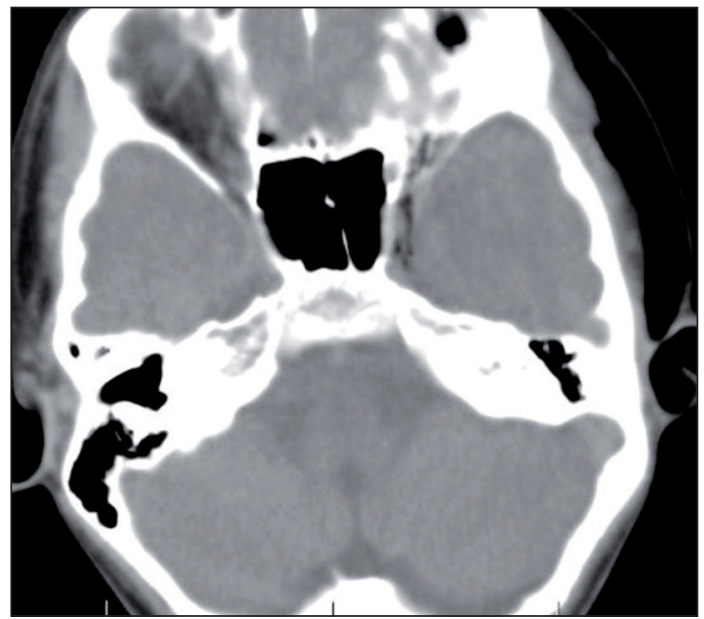

FIGURE 4: Pneumocephalus compatible with optic nerve path.

the weekly control and emphysema was observed to be fully resorbed in the $3^{\text {rd }}$ week (Figure 5).

\section{DISCUSSION}

Orbital emphysema usually occurs after a trauma to the orbital and facial region. ${ }^{6}$ Occurring without the orbital bone fracture is unusual, but rare cases caused by air damage under pressure have been reported as a rare cause of orbital emphysema. ${ }^{7}$ A case with orbital emphysema without laceration on the skin and conjunctiva has also been reported. ${ }^{8}$ The clinical symptoms of facial swelling, eyelid closure and extraorbital, subcutaneous emphysema occur in patients with air inlet into the orbital area. In addition, subconjunctival hemorrhage, crepitation, tenderness and pain may be present. ${ }^{9}$ Additionally, proptosis, emphysema under scalp, 2-mm-incision in the lower fornix conjunctiva has also emerged in our patient. While stretching and contraction of the eyelids are often available in the proptosis depending on orbital emphysema secondary to increased pressure inside the orbita, expansion in the range of eyelids are often seen in proptosis due to other causes. ${ }^{5}$ As in our case, to realize conjunctival laceration close to fornix is quite difficult due to narrow opening of eyelid in the pressurized air trauma. High pressure air coming has formed a hole in the conjunctiva which has caused emphysema in the periorbital, retro-orbital regions. Anatomically orbita is opened to the brain by way of the optic nerve in the back. In our case, high pressure air caused pneumocephalus by following this way.

Orbital emphysema is usually benign and selflimiting condition, but it can also cause distressing clinical conditions such as proptosis, loss of vision, increased intraocular pressure, and central retinal artery occlusion (CRAO) ${ }^{10}$ On the basis of these symptoms, patients are divided into four stages. Stage 1: Includes patients without complaints of CRAO, increased intraocular pressure, loss of vision or proptosis or the patients with air accumulation around the orbita clinically and radiological confirmed. Stage 2: Includes patients without complaints of CRAO, increased intraocular pressure and loss of vision but with proptosis. Stage 3: Includes patients with complaints of loss of vision and proptosis, intraocular pressure may or may not be increased, CRAO is not present. Stage 4: All the

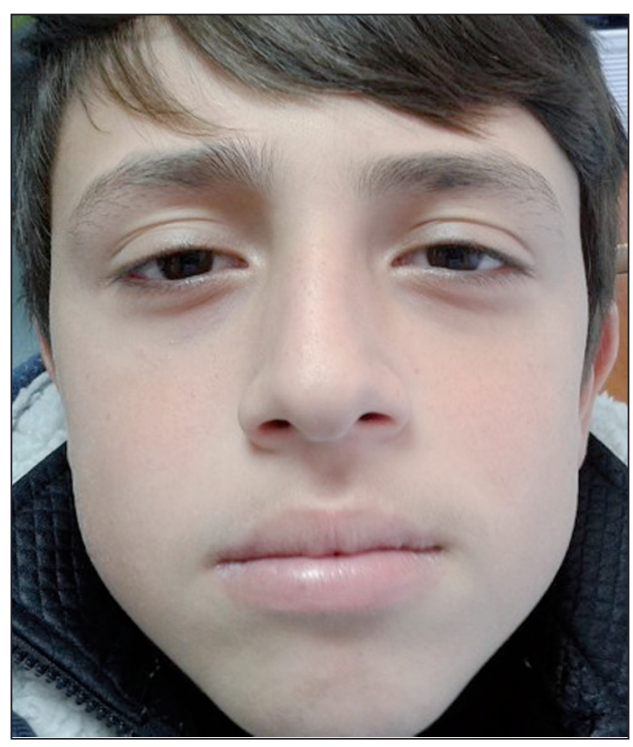

FIGURE 5: .Appearance at the end of the $3^{\text {rd }}$ week. 
signs and symptoms are present. While Stages 1 and 2 patients are treatedin the best way conservatively with observation, antibiotics and decongestants; Stage 3 and 4 patients need intravenous antibiotics, steroids, and emergency orbital decompression. Usually the diagnosis is base on clinical base and confirmed by radiology. ${ }^{10}$ Multislice computed tomography (CT) is particularly useful in detecting the small amount of air and reformatted images allows determining the exact location of the air. On CT examination, emphysema is identified in the orbital environment, scalp, retro-orbital region and intracranial space. ${ }^{11}$ Our case was accepted as stage 2 and consulted to neurosurgery clinic due to pneumocephalus. The patients was hospitalized for observation and antibiotic treatment and discharged in the $3^{\text {rd }}$ day of hospitalization due to the reduction of symptoms by regulating the treatment. Full recovery was observed in the $3^{\text {rd }}$ week. Stroh and Finger have reported a case of $8 \mathrm{~mm}$ of conjunctival laceration occurred due to pressurized air gun and secondary air in the subdermal, subconjunctival and retrobulbar area. ${ }^{12}$ Complete resorption of the air had taken detected to be occurred one month after the injury. Both Li et al. and Hitchings \&McGill have reported one case with orbital emphysema caused by air under pressure..$^{5}$ In these cases, fracture in the orbital bone as well as an inlet to the conjunctiva could not be found. However, it is likely that there is an air inlet into subconjunctival area and orbital cavity in such damage consisting of microlacerations which cannot be determined by clinical examination. Complications that can occur following orbital emphysema include glaucoma, uveitis, central retinal artery occlusion, optic atrophy, blowout fracture of the orbit and tearing of the ophthalmic veins with fatal air embolism. ${ }^{13,14}$

Our case is a rare case that emphysema was seen in the subconjunctival, orbital, retro-orbital, intracranial regions and under the scalp due to the trauma of a high pressure air gun. Bone and soft tissues around the orbit should be evaluated radiologically, if it is deemed necessary, consultations should be held with the relevant departments. Prophylactic antibiotic treatment should be given for every patient with orbital emphysema. During this period, patients should be followed regularly.

\section{Conflict of Interest}

Authors declared no conflict of interest or financial support.

\section{Authorship Contributions}

Concept: Kuddusi Teberik, Design: Kuddusi Teberik, Data Collection or Processing: Kuddusi Teberik, Mehmet Tahir Eski, Analysis or Interpretation: Kuddusi Teberik, Mehmet Tahir Eski, Murat Kaya, Literature Search: Kuddusi Teberik, Mehmet Tahir Eski, Written by: Kuddusi Teberik, Conflict of interest: There is no conflict of interest between authors.

\section{REFERENCES}

1. Muhammad JK, Simpson MT. Orbital emphysema and the medial orbital wall: a review of the literature with particular reference to that associated with indirect trauma and possible blindness. J Craniomaxillofac Surg 1996; 24(4):245-50.

2. Li T, Mafee MF, Edward DP. Bilateral orbital emphysema from compressed air injury. Am J Ophthalmol 1999;128(1):103-4.

3. Rzymska-Grala I, Palczewski P, Błaż M, Zmorzyński M, Gołębiowski M, Wanyura H. A peculiar blow-out fracture of the inferior orbital wall complicated by extensive subcutaneous emphysema: a case report and review of the literature. Pol J Radiol 2012;77(2):64-8.

4. Ord RA, Le May M, Duncan JG, Moos KF. Computerized tomography and B-scan ultrasonography in the diagnosis of fractures of the medial orbital wall.

\section{Plast Reconstr Surg 1981;67(3):281-8.}

5. Mathew S, Vasu U, Francis F, Nazareth C Transconjunctival orbital emphysema caused by compressed air injury: a case report. Indian J Ophthalmol 2008;56(3):247-9.

6. Tsai SH, Chu SJ. Orbital emphysema. J Trauma 2008;65(5):1200.

7. Caesar R, Gajus M, Davies R. Compressed air injury of the orbit in the absence of external trauma. Eye (Lond) 2003;17(5):661-2.

8. Hitchings R, McGill Jl. Compressed air injury of the eye. Br J Ophthalmol 1970;54(9):634-5.

9. Paquette M, Terezhalmy GT, Moore WS. Subcutaneous emphysema. Quintessence Int 2002;33(6):4789.
10. Singhai SK, Dass A, Singh GB, Singh Virk RD. Orbital pneumatocele. Indian J Otolaryngol Head Neck Surg 2003;55(4):292-3.

11. Yuksel M, Yuksel KZ, Ozdemir G, Ugur T. Bilateral orbital emphysema and pneumocephalus as a result of accidental compressed air exposure. Emerg Radiol 2007;13(4):195-8.

12. Stroh EM, Finger PT. Traumatic transconjunctival orbital emphysema. Br J Ophthalmol 1990;74(6): 380-1.

13. Walsh MA. Orbito palpebral emphysema and traumatic uveitis from compressed air injury. Arch Ophthalmol 1972;87(2):228-9.

14. King YY. Ocular changes following air-blast injury. Arch Ophthalmol 1971;86(2):125-6. 